\title{
Erratum to: Undefeated dualism
}

\section{Tomas Bogardus}

Published online: 21 March 2013

(C) Springer Science+Business Media Dordrecht 2013

\section{Erratum to: Philos Stud \\ DOI 10.1007/s11098-012-9962-Z}

As desired by the author, the corrected affiliation is given here.

The online version of the original article can be found under doi:10.1007/s11098-012-9962-z. 